\title{
Turkish Teachers' Views on Educational Digital Games
}

\section{Research Article}

\section{Gulsah METE ${ }^{1}$}

${ }^{1}$ Karamanoğlu Mehmetbey University, Faculty of Education, Department of Turkish and Social Sciences Education, Karaman, Turkey, ORCID: 0000-0003-0979-1630

To cite this article: Mete, G. (2021). Turkish teachers' views on educational digital games, International Online Journal of Educational Sciences, 13(2), 604-619.

\begin{tabular}{|c|c|}
\hline ARTICLE INFO & ABSTRACT \\
\hline Article History: & $\begin{array}{l}\text { Focusing on the evaluation of Turkish teachers' views on educational digital games, this study } \\
\text { adopted a case study. Utilizing interviews, the purpose of the study is to understand Turkish }\end{array}$ \\
\hline Received: 30.11 .2020 & $\begin{array}{l}\text { teachers' perceptions as well as their views about educational digital games, and consequently, to } \\
\text { evaluate not only the usages of these games in Turkish courses but also their contributions to the }\end{array}$ \\
\hline Available online: & instruction. Hence, the study included ten Turkish teachers, who work in İzmir province and use the \\
\hline \multirow[t]{13}{*}{ 03.05.2021 } & educational digital contents in their courses. Through the content analysis, the study revealed that \\
\hline & Turkish teachers have considered digital educational games as necessary in Turkish courses. The \\
\hline & teachers utilize these games to increase the students' motivations as well as academic achievements, \\
\hline & to make the courses more appealing and efficient, and to enhance learning and the retention of \\
\hline & learning while having fun at the same time. Vocabulary games such as word hunting, memory cards, \\
\hline & and quiz shows are the educational digital games used widely by the teachers. The study discovered \\
\hline & that these games are usually applied in the 5th and 6th grades. However, because of the high-stake \\
\hline & test and the lack of appropriate educational digital games for the 8th graders, they are not preferred \\
\hline & in the 8th grades. On the other hand, the problems related to these games are the insufficient ICT \\
\hline & infrastructures at schools, the cost of the educational digital games, and insufficient digital \\
\hline & educational games. Lastly, the study showed that the teachers do not regard themselves as competent \\
\hline & enough to develop such games. Accordingly, the implications for further studies and improvements \\
\hline & were suggested in the study. \\
\hline
\end{tabular}

Keywords:

Educational digital games, Turkish course, Turkish teachers, gen $\mathrm{z}$

\section{Introduction}

In our education system adopting a constructivist approach, it is aimed to raise individuals with high self-esteem, who can reach, analyze, interpret and produce knowledge as well as think critically and creatively. Hence, it is crucial to provide a student-centered learning environment fostering freedom. This is requested

\footnotetext{
${ }^{1}$ Corresponding author's address: Karamanoğlu Mehmetbey University

Telephone: +905378819584

e-mail: gulsahmete@kmu.edu.tr

DOI: https://doi.org/10.15345/iojes.2021.02.019
} 
by a generation that has thrived in the digital world. The gen $\mathrm{z}$ called "digital natives" are analytical and critical thinkers. With high self-esteem and free spirit, these children will have more different demands from education than the other generations. The great improvements in technology and subsequently other advancements have influenced education as well. With the introduction of computers, tablets, smartboards, and the internet to classes, methods, techniques, and strategies used in courses have changed and moved to the digital world. Thus, e-books, e-dictionaries, interactive contents, animations, and educational digital games have entered courses and instructions.

Game always has a place in every developmental stage of children whether it is digital or not. It maintains both entertainment and acquisition of knowledge, skill, and habits. However, with the digitalization of education, educational games are also required to turn into the digital. By considering particularly motivating and appealing aspects of the computers and internet on the gen $\mathrm{z}$, it is indispensable to use these kinds of games in courses. Educational digital games have been used as not only a tool to achieve lesson objectives but also entertaining activities. Turkish course is a course maintaining mother tongue education including four skills of the language as listening, speaking, reading, and writing, which also enhances the competence in both Turkish culture and intercultural understanding. Turkish courses are needed to be appealing to children in order to enhance their competence in the mother tongue, maintain their first language education properly, and adopt the cultural identity as well. Today, the children taking Turkish courses are analytical thinkers with high self-esteem and free spirit. As digital natives, they are required to take a course integrated with Information and Communication Technologies as well as the internet. Maintaining a Turkish course channeled through digital educational games might foster not only an entertaining learning environment but also the retention of learning. Therefore, it is considered that a study investigating the usages of digital educational games in the courses is needed since it might reveal the process of educational digital games and also possible problems during the application of them. Moreover, it might shed light on the place of these games in the achievement of Turkish course learning outcomes and students' attitudes as well as motivations towards Turkish courses. Therefore, this study is regarded that it will contribute to the knowledge-base.

\section{Educational Digital Games}

A game is defined as an entertaining activity with certain rules that develops intelligence and talents (TDK, 2020). The child who plays on her own or with her family in the preschool years acquires knowledge and habits about life through games. Game having a place in every age level of an individual can be played individually or in groups. An individual starting school keeps playing games both in courses and outside of classes. With the introduction of the computers and internet into our lives, the games children play might change as well. Similarly, the traditional educational games might turn into educational digital games with the integration of technology into the lessons. Gamification as educational digital games is software products enhancing learning outcomes. In other words, they are information systems, applications, and services produced due to course objectives, which are used to create more enjoyable experiences and to drive behaviors (Baptista \& Oliveira, 2019). Design documents for the gamification are prepared according to lesson objectives, and the lesson objectives embedded in the games are proposed to students. Students not only spend more enjoyable time but also achieve learning outcomes through motivating, exciting and entertaining aspects of the gamification. Considering the era children are born to as well as the time they spend on the internet, it is inevitable to make use of digitalization (Zin, Yue \& Jaafar, 2009).

Objectives and learning outcomes aimed in education might be achieved through the integration of computers and the internet into classes. Introducing the games on which children spend a lot of time to the digital platforms, and attaining the objectives through gamification are the techniques widely used in education. Educational digital games are utilized not only for proposing subject matter to students but also 
for fostering an environment to acquire and practice skills. In these games, students not only read and listen, but also are supported with skill developments such as strategic thinking, planning, and group decision making (Kirriemuir \& McFarlane, 2004). Shortly, students are active participants in their learning, and they have fun at the same time. Educational digital games are used as motivators for learning subject matter to warm-up, stimulate, and activate prior knowledge, as a structure for learning subject matter to facilitate learning, and as a representation of subject matter for practice (Linderoth, Lantz-Andersson \& Lindström, 2002).

Students can visualize abstract concepts with the help of educational digital games enriched with music, pictures and videos, etc. Therefore, abstract concepts become more concrete through gamification. Also, they can be utilized to help students keep on task as well as to increase their interests. When students participate in the games voluntarily, it will be easy for them to attain learning outcomes and transfer what they learn in class to real life. The educational digital games as an alternative or a supplementary to the techniques and methods used in classes have several benefits: Since the gamification includes real-life problems, they foster a real-life experience by creating the effect of immersion on players. Hence, they enhance the development of problem-solving skills. They propose boring and challenging topics in an enjoyable way, which helps to facilitate learning. Through gamification, the subject matter might be reinforced by having fun as well. As they motivate and stimulate students, they actively participate in tasks. Because of students' active and willing participation, the educational digital games with rich components contribute to the development of selfreliance as well as cognitive skills (Gee, 2003). Also, experiments or implementations, which can be challenging and dangerous to perform in daily life, might be experienced virtually through simulation. This simulation makes abstract concepts concrete and subsequently learning retention. Hence students having the opportunity to learn by experiencing and living will have achieved the objectives aimed in education (Ural, 2009; Şahin \& Samur, 2017).

Movement of Enhancing Opportunities and Improving Technology (Fatih) Project can be given as an example for the reflection of the science and the technology improvements to education. Within the scope of this project, Education Information Network (EBA), which is an online social educational platform promoted by the Ministry of National Education, aims to establish communication between teachers and students, and also to offer educational digital materials to students in education. EBA has supported the distant education process with a great variety of the educational contents on instructional and interactive materials such as games, e-books, etc. Teachers have reached their students, given their instructions and assignments through this online social educational platform. Consequently, EBA contributes to education since it provides several materials such as digital games, interactive content, infographics, animations, and simulations.

\section{Educational Digital Games and Turkish Language Instruction}

Turkish language curriculum (MEB, 2019) comprises the skills and competencies such as digital competence, digital literacy, media literacy, and information literacy. Additionally, it is suggested to utilize ICT and digital materials in the implementation of the curriculum. There is a limited number of studies examining the usage of educational digital games in Turkish courses, and also recent studies have been focusing on this issue (Özcan \& Yavuz, 2020; Aşc1, 2019). Proposing an appropriate language education to today's children, who are compatible with the individuals aimed in Turkish education's general objectives and taking advantage of their high qualities seem to be very crucial. Thus, for Turkish courses, there are digital contents such as simulations, animations, educational digital games, word processing software, infographics, Kahoot, interactive applications and e-books, etc. in both EBA and other digital platforms even if they are in limited numbers.

The digital materials related to listening, speaking, reading and writing skills enhance the active participation of students at different levels, and consequently, the more efficient and productive learning 
environment is achieved (Aşc1, 2019; İşcan, 2005; Belet Boyacı \& Güner, 2017; Ocak, 2013). The educational digital games used in Turkish courses increase students' motivation and interests towards the course and decrease their anxiety as well, which leads to students' academic achievements (Buckley \& Doyle, 2016; Altunbay \& Bıçak, 2018; Aşc1, 2019b). The usage of these games fosters an entertaining learning environment, which provides the retention of the subject matter. On the other hand, it supports the development of several skills such as decision-making, problem solving, focusing, and using the technology, etc. (Bal, 2018; Boz, 2018; Akçay \& Şahin, 2012). The digital games particularly used in concepts, jargon, and vocabulary teaching enhance concretion and build the relationship between concept and fact (Özdemir, 2017). Since gamification promotes real-life experiences, it stimulates students. The digital games including design documents prepared due to learning outcomes of four skills might be utilized in the instruction of every topic as well as every stage of the lesson, and they might be very beneficial (Önkaş, 2008). With the help of visuals, audio, and interactive games and videos (Griffiths, 2002), active participation of students in Turkish courses is achieved (Baki, 2016; Ertem, 2016). With the digitalization of the in-print materials such as book, magazine, newspaper, etc., students' motivation and interests toward reading are increased; the digital applications might help them to develop a reading habit since they are able to reach books easily (Özerbaş \& Öztürk, 2017). The implications for the usage of electronic storybooks in Turkish courses and the number of these kinds of studies have raised recently (Özcan \& Yavuz, 2020; Dayan \& Girmen, 2018). Because of the e-storybooks used in Turkish courses, students' reading and listening skills, namely comprehension skills have been developed with an increase in their vocabulary, and also, their writing skills have been improved since they have the opportunity to recognize spelling and punctuation rules (Becel, 2013; Işık, 2013; Bal, 2019). Including audio components, the educational digital games develop students' listening and speaking skills. Qualified audios enhance pronunciation learning, intonation, and stress recognition as well as the development of listening skill strategies. Besides, the visual components in addition to audios help students engage multiple senses, and subsequently facilitate learning and the retention of knowledge. Speaking and listening rules might be proposed easily through educational digital games. The games played with groups increase students' interactions and communication, which fosters cooperative learning as well as peer learning. Students, who can communicate, obey speaking and listening rules while paying attention to the game rules. Also, the instant feedbacks included in the educational digital games provide interactions, which enhances the opportunity for students to check their learning process immediately. Thus, they motivate students more towards the course and increase their sense of self-esteem as well. Moreover, playing against time in educational digital games assists students to develop their skills of thinking, and deciding quickly. Students who try to solve the problems proposed in the games will be able to transfer them to real-life problems and experiences, which enhances the problem-solving skill development subsequently. On the other hand, the sense of rivalry and competition creates an exciting environment, which increases students' interest towards the course. Also, several skills related to 21st-century skills such as visual literacy, information and media literacy, critical thinking, thinking analytically, problem-solving, interpretation and sequencing, learning vocabulary and vocabulary development, etc. might be acquired through educational digital games. Apart from it, they might be helpful in students' development of some other values and competencies such as obeying rules, being patient and respectful. Despite the limited numbers, there are some studies on the usage of educational digital games in Turkish courses in the literature. These studies revealed that the educational digital games increased students' achievements as well as motivations while they fostered a positive attitude development, and an entertaining environment in Turkish language education (Akçay \& Şahin 2012; Aşc1, 2019b; Yüksel, 2019). Moreover, a study on preschool students discovered that educational digital games played a role in the development of phonological awareness skills (Tecen, 2018). Hence, through letter games, teaching the alphabet might be done, and with the help of writing games, writing skills might be improved as well. 
Turkish teachers can utilize the educational digital games played in every stage of students' development at any time of a lesson. For instance; they can be used to evaluate the lesson, to do students' assessments, to develop four skills of language, to give grammar and structure instruction, as well as value education, to motivate, to activate prior knowledge, to present the subject and to reinforce learned topics. Also, Turkish teachers can not only select an appropriate educational digital game according to their lesson objectives but also design a new one. Thus, teachers can increase their students' motivation towards Turkish course, achievements, and also enhance the retention of learning.

\section{The Purpose of the Study}

The main purpose of this study is to understand Turkish teachers' views and perceptions of educational digital games. Hence, this study was conducted to investigate the usage and contribution of the educational digital games in Turkish courses by exploring the teachers' views and perceptions. With this purpose, the questions below were developed.

1. What do the Turkish teachers think about the EDG in Turkish courses?

2. How do the Turkish teachers evaluate themselves in terms of the application of the EDG?

\section{Research Design}

This study adopted a single case study in which the case within its boundaries are analyzed and described with a holistic manner (Yıldırım \& Şimşek, 2011). In this study, the usages of the educational digital games in Turkish courses were studied through the interviews with the teachers. Turkish teachers' usages of digital educational games in their courses, and how they utilize them, and the degree of their usages as well as how they consider themselves in the application of these games are analyzed and described with a holistic perspective.

\section{Participants}

The participants of the study included Turkish teachers utilizing the educational digital games in their courses, who were purposefully selected by using a criterion sampling strategy. In this sampling strategy, the participants meeting the criteria, which are identified before the study or developed by the researcher (Yıldırım \& Şimşek, 2011) are chosen for the study. Accordingly, 5 male and 5 female Turkish teachers working in public schools in İzmir province attended the study. By varying across their graduation, one of the teachers had P.h.D degree, three of them had a Master's degree, and the others had a bachelor of art degree.

\section{Data Collection and Analysis}

The ethical permission required for data collection in the study was obtained from the Scientific Research and Publication Ethics Committee of Karamanoğlu Mehmetbey University Rectorate (22.02.2021 date / E-6158). The data were collected through the interviews. Before employing the interviews, an interview protocol including open-ended items was prepared by the researcher and it was sent to two experts to obtain the validity. By using expert opinions, the questions were modified. Then, it was piloted with two Turkish teachers, and some modifications on the phrases were needed. By doing the needed change, it was decided that the interview was clear enough to utilize in the study. The interviews were conducted over the phone and they were recorded with the consent of the participants. The example questions directed to the participants are as follows:

- How do you define the educational digital game (EDG)?

- Could you use EDG efficiently in your classes? Are there any factors affecting your usage process? 
- Have you ever designed any EDG or other digital materials for your lessons? Do you have any further studies in this field? If yes, could you explain them?

The data were analyzed by using content analysis, in which the interview data were categorized. Then, the themes were obtained according to the purpose of the study. Considering the validity of the study, the researcher tried her best to understand accurately the participants' inside and views without any bias. Moreover, after naming the codes, they were controlled by conducting both a peer review including two experts, who were familiar with the research and check-coding (Miles \& Huberman, 2015). Hence, the same data set were coded by different researchers and they were checked through a discussion to decide whether a reliability check was achieved or not. For the reliability check, the formulation, which is Reliability = number of agreements/ total number of agreements+ disagreements, proposed by Miles \& Huberman (2015) was utilized. Accordingly, the intercoder reliability of this study was calculated as $90 \%$. Apart from it, the findings were supported with the direct quotes of the participants represented with the acronyms such as T1, T2, T3 etc.

\section{Findings}

The findings were displayed through the titles generated according to the themes.

\section{Themes on the RQ1}

\section{Turkish Teachers' Perceptions of Educational Digital Games}

According to Turkish teachers, utilizing digital content in teaching and learning has been defined as an activity of teaching and having fun at the same time, and also achieving the lesson objectives more easily by using the technological devices efficiently with or without the internet. The educational digital game has been described as the digital content enriched with interactive components such as audio and visual, used mostly for reinforcement, accessed through the devices like computers, mobile phones, tablets, and smartboards, and also an alternative teaching method to attain the lesson objective by playing games online.

\section{The Significance of the Educational Digital Games in Turkish Courses}

Turkish teachers have emphasized the significance of educational digital games in Turkish courses as the case in other courses. By giving reasons, they have explained for what purposes they have been using the educational digital games in their classes. They have considered these games as significant because the educational digital games both increase the motivation and concentrations of the students, who are true digital mavens, and enhance a fun and efficient way of Turkish language education, which eventually leads to the retention of learning. Also, the teachers have used these games for the reinforcement of the subject, making associations with real-life, and giving the instructions in an enjoyable and efficient way.

T1: “It's necessary for Turkish course as it is in all the courses. I guess it will increase the students' motivation towards the course, and their concentrations as well."

T2: "It is certainly necessary. It is important regarding its effects such as making learning more enjoyable and efficient, (and also) increasing the students' interests. In a period when the children live and breathe with the technology and the internet, it is needed to make use of it in teaching and learning."

T3: "It is significant to increase the students' interests. Today, the students are more interested in the contents including the visuals, music, and audio. Also, the students find these kinds of games used for the reinforcement more interesting."

T5: "The educational digital games are necessary. They are significant to teach the subject by uncovering the students' cognitive, behavioral and social skills through having fun at the same time." 
T7: "They are significant because they ease learning by presenting the subject in an enjoyable way. Especially regarding the pandemic we live, they are very efficient."

T9: "They are necessary. In a digitalized world, we have to keep up with these advancements. Also, diversity is in the foreground of future education models. The educational digital games are new favorites of the children in this century."

\section{The Usages of the Educational Digital Games in Turkish Courses}

While mentioning their usages of the educational digital games in their classes, the Turkish teachers have explained their usage frequencies as follows: Some of them have explained that they have allocated one hour weekly to the usage of the educational digital games for a five or six-hour weekly Turkish course. Also, some other teachers have mentioned that they have used these games when needed. On the other hand, some teachers have told that they have utilized these games particularly in the supplementary courses, not in the weekly compulsory courses.

T1: "I often use them after each text instruction and at the end of a unit."

T2: "Not too often. I sometimes use them in my classes when the conditions are met."

T3: "I certainly allocate my one hour in a week to the interactive applications for a five or six-hour weekly Turkish course. Sometimes, this time might be two hours depending on the subject or content."

T8: "After each grammar instruction, I try to use them. Not in my Turkish classes (compulsory Turkish courses) but in my supplementary classes, I definitely use them."

Turkish teachers have mentioned also the factors hindering the usages of the educational digital games in addition to the benefits of them such as motivating the students, making the instruction effective and contributing to reaching the objectives.

The current educational digital games are not sufficient considering the objectives in the Turkish language curriculum, and also there is a lack of information, time, and competence regarding teachers' qualities to design the educational digital game as well as a lack of ICT infrastructure. There are not sufficient educational digital games to be played in the classrooms with groups. Also, The current games the teachers have found have not been organized according to the lesson objectives or the subjects. All of these issues are the factors hindering the usage of educational digital games efficiently.

T1: "I think that they are efficient (in teaching). But they are not so common. To access and find them is not so easy. They are not found for each class level."

T2: "I believe that I use them efficiently. (However,) The fact that I do not have sufficient knowledge about the digital games is a factor affecting my usage as a routine."

T3: "I use them efficiently in my classes. I have observed that they have very good results in attaining especially listening skills. The negative factors affecting my usage is the problem with the ICT infrastructure at schools."

T6: "I cannot use them very efficiently. As the design of them is very difficult and the current ones are not the way I want (form y teaching), I cannot use them efficiently."

T8: "I cannot find a game including the content I want, and the educational digital games are not convenient to play as a competition in groups, and they are not also convenient for multiplayer. These are the factors hindering my usage effectively."

T10: "The reason why they are not efficient is the fact that we do not have enough time, infrastructure, and educational digital games. The current ones demand payment or they are in limited access. 


\section{The Educational Digital Games Used in Turkish Courses}

The Turkish teachers have been using digital games such as word games (Wheel of fortune etc.), vocabulary development games, memory cards, and quiz shows. At the same time, they have been utilizing the digital contents to attain listening and reading skills as well as the objectives related to grammar teaching. Moreover, they have explained that they have used e-books, e-storybooks, animations, and interactive applications when they cannot find an appropriate educational digital game.

T1: “Generally, I use educational digital games like Wheel of fortune in vocabulary instructions."

T3: "I use the digital contents like tales, ads, and public service ads to attain especially the listening skills. Also, these applications are more appealing than the traditional implementations in the instruction of grammar structures such as gerundial phrases and basic sentence structures."

T8: "I often use word hunting and informational games and contest games."

T10: "Since it is easy to find vocabulary development and word hunting games, I usually use them. Also, I utilize e-storybooks, animations, and interactive applications mostly."

\section{The Usage of the Educational Digital Games According to Turkish Language Skills and Subjects.}

The Turkish teachers have emphasized the importance of using educational digital games at every class level. They have mentioned that the best classroom levels for the usages are particularly 5 and 6th grades. According to the teachers, the educational digital games are not suitable for the 8th grade because of both the high stake test in the 8 th grade and the difficulty in reaching these games for this grade. Therefore, they have explained that they could not use them in the 8th grade.

The Turkish teachers have also asserted that Turkish language education should be offered with a holistic approach, in which the instruction of four skills should be given in an integrated way. Although they have mentioned that the educational digital games will be effective in teaching all of the skills as long as these games are provided as ready-to-use, they have noted that they have used these games especially for the development of listening and reading skills. Also, they have stated the educational digital games are beneficial for grammar instruction as well.

T1: "They have great contributions to grammar and reading."

T2: “They are beneficial for listening, speaking, reading, writing skills."

T3: “They are more effective for listening and reading skills, but I cannot deny their benefits in other fields."

The Turkish teachers have stated that educational digital games are effective activities to teach skill strategy, grammar, word types, vocabulary, and punctuation rules.

T2: "I think that they are more effective in teaching grammar, lexis, the semantics, for instance."

T3: "You can achieve better results when you use them for listening skills, visual literacy, and grammar instruction."

T6: "Since the subjects of phonological change and punctuation are challenging and need more practice, the educational digital games would be more effective in the instruction of them, I guess."

\section{The Benefits of the Educational Digital Games}

The Turkish teachers have evaluated the contributions of the educational digital games regarding the teacher, students, and classroom management. Accordingly, educational digital games are quite beneficial to attract students, who have problems of concentration and low motivation. As they provide high participation of students, it is easier and effective to give the instruction of the subject matter as well as in a more enjoyable 
way. The subject matter is reinforced and subsequently, the retention of learning is enhanced, which helps students to transfer the subject matter to real-life. Lastly, the teachers have mentioned that using a different method to raise Turkish course academic achievement would have potentials for both teachers and students.

Apart from the positive aspects of the educational digital games, the teachers have emphasized that the Turkish teacher to utilize these games should have the needed information, technological competence, ICT infrastructure, and time as well. Also, they should provide the required guidance for students, and they should be careful about time management in the implementations. Otherwise, the educational digital games used in the classes might lead to some undesired results.

T1: “They are the activities attracting the students' attention, who have concentration issues. In this sense, they might help the teacher. Moreover, they might assist the students to learn more easily, but the cost of these activities is the time. They take too much time."

T3: "They show us the Turkish class is not just a means of reading the texts and answering the text questions in the course books. They help us to understand how much a Turkish class gives prominence to the imagination, and how it encourages us to think. These games do not affect our classroom management skills negatively. On the contrary, they increase the students' interest. However, they might cause some distractions for some 8th graders. Particularly, to include the students, who do not have any purpose, in these activities is hard. As they do not participate in subject matter instructions actively, they are unwilling to do the practice as well."

T4: "They enhance the students' active involvement. The students have fun at the same time. When the teacher recognizes the students' enjoyment and learning, s/he enjoys it as well. This affects classroom management positively. When the achievement increases, the classroom management gets easy."

T6: "They provide a different and fun way of learning in terms of the students. Regarding teachers, they enhance an easier way of teaching and the opportunity for reinforcement. Surely, they have benefits in terms of classroom management. However, it needs great attention to employ them. When needed guidance is not provided, they will have no benefits."

T7: "By increasing the interaction, they have benefits to improve the student-teacher and peer relationships. They change the students' attitude towards the course and the sense of rivalry. As they might cause problems regarding classroom management in crowded classes, they might be used in online education more efficiently and easily. They help the students to focus on the course during the screen time."

T8: "Regarding the teachers, they foster learning in a short time and the students' motivations towards the classes. For students, they provide an escape from boring lesson time, and great contributions to their learning by considering them as early adolescents, who still like games and fun. In my opinion, they will have benefits regarding classroom management. Because the students whose focuses are on the games will behave more accommodating in showing more efforts to collaborate and participate in decision making."

T9: “They will reduce the teachers' workload, and foster an enjoyable learning environment. Classroom management might be affected both negatively and positively. For a teacher who does not have digital competence, they cause negative results. However, for a teacher who is highly competent in the technology, they are advantageous to use them in classes."

\section{The Degree of the Turkish Teachers' Access to the Educational Digital Games}

The Turkish teachers make use of platforms offered by both EBA and publications (Morpa Kampüs, Okulistik) as well as the social platforms to access the educational digital games. On the other hand, some teachers have explained that they have used some digital design tools (storyline, construct) to develop their materials or they have used some games by revising them. 
T1: “There are some packs we bought, but they are prepared by teachers for their classes. I use them by making some changes. EBA has also become an effective platform offering sources."

T3: "I usually utilize the sources such as Morpa and Okulistik. Also, I have been making use of EBA recently. I try to develop materials by using the programs such as storyline and construct."

T7: "I use the website named www.mustafa-turan.com"

T9: "I make use of EBA and other websites like http://izmir.meb.gov.tr/oyunatolyesi, http://tegmmateryal.eba.gov.tr/"

The Turkish teachers have also evaluated EBA, which has become the main topic during the pandemic and online education, in terms of the educational digital games. Although it is considered a good source during the pandemic, it is regarded as inefficient in terms of educational digital games. Also, the improvements done in EBA have a role in the teachers' positive regards towards it.

T3: "I do not consider EBA as sufficient. There is no content for each objective and subject. Let's give an example. If you would like to present a game while having a class about Karagöz and Hacivat, you cannot find a game for that instance. It is available in the other digital platforms, but it is not allowed to access them with the internet provided at schools."

T8: "No, I do not regard EBA as sufficient. It offers us the contents on multiple questions and videos mostly." T9: “No, I do not consider EBA sufficient. The contents are not organized and filtered. Those contents should be revised by the experts in the field."

The Turkish teachers have evaluated the educational digital games they have accessed. Firstly, they have emphasized how difficult to find an appropriate game for each objective as well as to access them. The teachers have criticized the available ones because they request a lot of money, and they have insufficient knowledge, questions, or mistakes. They have noted that the revision of the games takes too much time. They have pointed out the lack of the games developed professionally.

T1: "It is difficult to access them. It is almost impossible to find an appropriate educational digital game for each grade. They cannot be utilized for all the grades. They are not common. Mostly, I spend time on changing and adapting the games to the grade level."

T3: "They are in limited numbers, which is a limitation of the educational digital games. I think that they will be appealing when an appropriate one is offered for each objective. However, some of them are just usual activities such as gap filling and matching."

T8: "They are not economic and include few questions and mistakes. They are not convenient for reading and listening skills or with limited numbers. Unfortunately, the available ones are just for grammar instruction."

T9: “They are far beyond the modern games because of the programs in which they were developed. I think more developed programs should be conducted in their design."

\section{Themes on the RQ2}

\section{The Turkish Teachers' Educational Digital Game Competence}

The Turkish teachers have mentioned that they are not competent enough to both develop and use educational digital games. They have emphasized that they need a professional development activity to do this. Some of them have stated that they are willing to design games and they have worked on that. 
T1: "We have things needed to improve, of course. We need to take pedagogical training in this field. I change and adapt the contents developed by others to make them appropriate to my class and subject. I rarely develop games by myself, but they are a bunch of quite amateurs."

T2: "I do not regard myself as competent to use the educational digital games as a teaching method. I need a professional development activity in this field."

T3: "We have to take good training on the ICT to be competent enough in the educational digital games. Because these games include graphics, vectors, and coding. I do not see myself as competent in this field, but I try to do inquiries and works related to this issue. Once again, the importance of ICT in education has been proved during this pandemic. I have developed some games on proverbs and idioms. I have observed that the students learn them better through activities such as puzzles, games, and tales. I work for the team of the digital content development in İzmir."

T9: “Yes, I feel competent, but there is no limit in learning. I am open to every kind of information. I have designed educational digital games to use in my classes. I work on it specially. I work for the team of the digital content development in İzmir."

\section{Conclusion and Discussion}

The results of this study on the Turkish teachers' views about educational digital games as well as the other studies related to this study have been displayed in this section. The educational digital games perceived as teaching through enjoyment and including the digital games in the education has been defined as the games in which the lesson objectives embedded. Also, according to the teachers, they are the games including visuals, audio, and music played by both one player and multiple players through a device such as a computer, mobile phone, tablet, and smartboard.

Turkish teachers believe that educational digital games are fundamental in Turkish courses as the case in other courses, which is similar to the result of the study by Belet Boyacı and Güner (2017). This study has revealed that the teachers have viewed the digital content positively. Once again, Ertem (2016) finds out a similar result in the study examining the classroom teachers' views about the usage of the game-based digital content in Turkish courses. The educational digital games are used to increase the motivations of the gen $\mathrm{z}$ breathing and living the technology as well as their academic achievements, to make the instructions efficient and enjoyable, to enhance the retention of learning, and to teach while having fun. Similarly, Akçay and Şahin (2012) point out that the teaching method of Webquest has a critical role in the students' development of attitude and achievement towards Turkish courses.

Aşcl (2019b) and Yüksel (2019) have also observed that educational digital games enhance the students' motivation, enjoyment, and attitudes. Tecen (2018) emphasizes that these kinds of games have a pivotal role in phonological awareness education. The Turkish teachers usually utilize educational digital games in their classes. According to the results of the study, some of the teachers allocate two hours to these games in a week, and some others use them in their supplementary classes. Although the teachers consider them as efficient in their instructions, they have also stated the factors hindering the effective usages of these games. These factors are the technical factors such as the lack of the needed infrastructures in the classrooms, the lack of sufficient educational digital games considering the Turkish course objectives, the cost of the available games, and the teachers' digital competence.

The Turkish teachers utilize word hunting, vocabulary development games, memory cards, and quiz show in their classes mostly. Additionally, they use digital materials such as interactive applications, animations, digital stories, and e-books. The educational digital games are mostly applied in the 5th and 6th grades, and they are not preferred in the 8th grades because of the high-stake tests and insufficient educational 
digital games appropriate for this grade. They are implemented in the development of listening and reading skills more and particularly they are considered effective in grammar instruction. Presenting abstract concepts through games provides learning better as well as the retention of learning. The role of the educational digital games in teaching structures, vocabulary, punctuation, and grammar has been emphasized, which is studied in the knowledge-base. Becel (2013) and Bal (2019) suggest making use of digital games in the instruction of writing skills. Aşcı (2019b) has observed the increase in the students' success in the study on morphology teaching through educational digital games. Önkaş (2008) states that these kinds of games are beneficial in the development of all language skills.

The study has uncovered that educational digital games have benefits regarding teachers, students, and classroom management. The researchers examining the usages of these games in both Turkish education and other school subjects have also reached this result. While the Turkish teachers give the instructions more effectively and easily, the students have the opportunity to get knowledge by experiencing and having fun at the same time during educational digital games implementations. Active participation of the students affects the classroom management positively (Akçay \& Şahin, 2012; Aşc1, 2019; Özdemir, 2017; Becel, 2013; Kablan, 2010; Şahin, 2016; Yıldırım, 2015; Yazıcıoğlu, 2017; Ural, 2009).

The Turkish teachers use not only EBA provided by the Ministery of National Education but also the platforms offered by the publications (Morpa Kampus, Okulistik, etc) as well as the social media to find the educational digital games. Also, the study has discovered that EBA has been considered insufficient to achieve The Turkish course objectives.

According to the Turkish teachers, it is difficult not only to have an access to all the educational digital games but also to find an appropriate one for all the objectives of the Turkish course. Another result of the study is the cost of the available games, which is very high. The educational digital games have been considered insufficient because of some reasons such as including few questions, mistakes, and being designed for just grammar instruction. The professionally developed games are in limited numbers and to modify or adapt them has been found as time-consuming. Apart from it, the study uncovered that the Turkish teachers do not regard themselves as competent enough both to use and develop educational digital games even if they display efforts to use these kinds of games in their courses. Therefore, they have asserted that they need to be supported with professional development activities.

\section{Implications}

According to the results of this study, the implications can be suggested as follows:

Appropriate educational digital games for listening, speaking, reading, and writing skills should be developed and designed. The current ones should be revised and improved.

The ICT infrastructure of schools and limitless internet access to all digital platforms should be provided.

The Turkish teachers including the candidate ones should be supported with the professional development activities in this field to have teachers who can design, produce their materials, and enact implementation process.

The digital contents and the educational digital games offered in EBA should be organized and filtered by the experts according to the objectives and subject matters, which will make these materials more efficient and operational. 


\section{Limitation}

This study is limited to the data obtained through only interviews. Therefore, it is suggested to conduct a study utilizing other instruments such as observations, students' and parents' views for deeper understanding into the usages of the educational digital games in future. Moreover, by utilizing different kinds of research designs such as mixed methods or empirical research, the knowledge-base on the usages of the educational digital games in Turkish course as well as other courses might be enriched and supported. 


\section{REFERENCES}

Akçay, A. \& Şahin, A. (2012). Webquest (Web Macerası) Öğrenme Yönteminin Türkçe Dersindeki Akademik Başarı ve Tutuma Etkisi. Ĕ̆gitim Bilimleri Araştırmaları Dergisi, 2(2), 33-45.

Altunbay, M. \& Bıçak, N. (2018). Türkçe Eğitimi Derslerinde "Z Kuşağı" Bireylerine Uygun Teknoloji Tabanlı Uygulamaların Kullanımı. Zettschrıft Für Dıe Welt Der Türken, 10(1), 127-142.

Aşc1, A. U. (2019a). Oyun Temelli Öğrenme Yönteminin Öğrencilerin Türkçe Dersine Yönelik Başarı ve Tutumlarma Etkisi (Yayımlanmamış Yüksek Lisans Tezi). Kırşehir Ahi Evran Üniversitesi Sosyal Bilimler Enstitüsü, Kirşehir.

Aşcı, A. U. (2019b). Eğitsel Dijital Oyunların 6. Sınıf Öğrencilerinin Türkçe Dersi Akademik Başarılarına Etkisi. Uluslararası Sosyal Araştırmalar Dergisi, 12(62), 932-941.

Baki, Y. (2016). Ortaokul Öğrencilerinin Türkçe Dersinde Eğitsel Oyunların Kullanımına ve İşlevlerine İlişkin Görüşleri. 3. Uluslararası Gençlik ve Çocuk Edebiyatı Sempozyumu (s. 289-308). İstanbul: Çocuk ve Gençlik Edebiyatı Yazarları Birliği.

Bal, M. (2018). Çok Katmanlı Okuryazarlık Bağlamında Oyunlaştırmanın Türkçe Öğretim Sürecine Katkısı. Ana Dili Ĕ̆itimi Dergisi, 6(1), 183-201.

Bal, M. (2019). Use of Digital Games in Writing Education: An Action Research on Gamification. Contemporary Educational Technology, 10(3), 246-271.

Baptista, G. \& Oliveira, T. (2019). Gamification and Serious Games: A Literature Meta-Analysis and Integrative Model. Computers in Human Behavior, 92, 306-315.

Becel, A. (2013). Bilişim Teknolojileri Ekseninde Yazarlık ve Yazma Becerileri Dersine Yönelik Bir Değerlendirme. Turkish Studies-International Periodical for the Languages, Literature and History of Turkish or Turkic, 8(3), 61-81.

Belet Boyacı, Ş. D. \& Güner, M. (2017). Türkçe Dersinde Teknolojik Otantik Ortamın Kullanılmasına Dair Öğrenci ve Öğretmen Görüşleri. Anadolu Journal of Educational Sciences International, 7(1), 35-71.

Boz, İ. (2018). İlkokul 4. Sınıf Türkçe Dersinde Oyunla Öğretim Yönteminin Akademik Başarıya Etkisi. Sosyal Bilimler ve Eğitim Dergisi, 1(1), 61-75.

Buckley, P. \& Doyle, E. (2016). Gamification and Student Motivation. Interactive Learning Environments, 24(6), 1162-1175.

Dayan, G. \& Girmen, P. (2018). Türkçe Eğitimi Yazma Sürecinde Dijital Öyküleme. Eğitimde Nitel Araştırmalar Dergisi - Journal of Qualitative Research in Education, 6(3), 207-228.

Ertem, İ. S. (2016). Oyun Temelli Dijital Ortamlar ve Türkçe Öğretiminde Kullanımına İlişkin Sınıf Öğretmenlerinin Görüşleri. Akdeniz Ĕ̆gitim Araştırmaları Dergisi, 20, 1-10.

Gee, J. P. (2003). What Video Games Have to Teach Us About Learning and Literacy. Computers in Entertainment (CIE), 1(1), 20-29.

Griffiths, M. D. (2002). The Educational Benefits of Video Games. Education and Health, 20(3), 47-51.

Işık, A. D. (2013). Dijital Kitapların Eğitimde Kullanılabilirliği. Bartın Üniversitesi Eğitim Fakültesi Dergisi, 2(2), 395-411.

İşcan, A. (2005). Çoklu Ortam Aktiviteleriyle Bir Kavak ve İnsanlar Adlı Kısa Hikâyenin Öğretimi. Kâzım Karabekir Ĕ̆itim Fakültesi Dergisi, 12, 35-51. 
Kablan, Z. (2010). Öğretim Sürecinde Bilgisayara Dayalı Alıştırma Amaçlı Oyun Kullanılmasının Eğitim Fakültesi Öğrencilerinin Akademik Başarısına Etkisi. Kuram ve Uygulamada Ĕ̆itim Bilimleri Dergisi, 10(1), 335-364.

Kirriemuir, J., \& McFarlane, A. (2004). Literature Review in Games and Learning (Futurelab Series, Report 8). Bristol, UK: Futurelab.

Linderoth, J., Lantz-Andersson, A., \& Lindström, B. (2002). Electronic Exaggerations and Virtual Worries: Mapping Research of Computer Games Relevant to The Understanding of Children's Game Play. Contemporary Issues in Early Childhood, 3(2), 226-250.

MEB, (2019). Türkçe Dersi Öğretim Programı (İlkokul ve Ortaokul 1, 2, 3, 4, 5, 6, 7 ve 8. Sinıflar). Ankara: MEB Yayınları.

Ocak, M. A. (2013). Eğitsel Dijital Oyunlar: Kuram, Tasarım ve Uygulama, Ankara: Pegem Akademi.

Önkaş, N. A. (2008). Türkçe Öğretiminde Teknoloji Kullanımı ve Kalııı Öğrenme. 8th. International Educational Technology Conference (s. 811-816). Eskişehir: Anadolu Üniversitesi Eğitim Fakültesi.

Özcan, M. \& Yavuz, S. (2020). Digital Content in Graduate Level in Turkey: A Content Analysis of Twenty Years. African Educational Research Journal, 8(2), 201-209.

Özdemir, O. (2017). Türkçe Öğretiminde Dijital Teknolojilerin Kullanımı ve Bir Web Uygulaması Örneği. Turkish Studies: International Periodical for the Languages, Literature and History of Turkish or Turkic, 12 (4), 427-444.

Özerbaş, M. A. \& Öztürk, Y. (2017). Türkçe Dersinde Dijital Hikâye Kullanımının Akademik Başarı, Motivasyon ve Kalıc1lı Üzerinde Etkisi. TüBAV Bilim, 10(2), 102-110.

Şahin, H. B. (2016). Eğitsel Bilgisayar Oyunlarıyla Destekli Matematik Öğretiminin Öğrencilerin Akademik Başarılarına ve Duyuşsal Özelliklerine Etkisi (Yayımlanmamış Yüksek Lisans Tezi). Eskişehir Osmangazi Üniversitesi Eğitim Bilimleri Enstitüsü, Eskişehir.

Şahin, M. \& Samur, Y. (2017). Dijital Çağda Bir Öğretim Yöntemi: Oyunlaştırma. Ege Ĕ̆itim Teknolojileri Dergisi / Journal of Ege Education Technologies, 1(1), 1- 27.

Tecen, B. (2018). Okul Öncesi Dönem Ses Eğitiminde Dijital Oyun Temelli Destekleyici Aktivitelerin Çocuklarm Sesli Harfleri Öğrenmelerine Etkisi (Yayımlanmamış Yüksek Lisans Tezi). Bahçeşehir Üniversitesi Eğitim Bilimleri Enstitüsü, İstanbul.

Ural, M. N. (2009). Eğitsel Bilgisayar Oyunlarının Eğlendirici ve Motive Edici Özelliklerinin Akademik Başarıya ve Motivasyona Etkisi (Yayımlanmamış Doktora Tezi). Anadolu Üniversitesi Eğitim Bilimleri Enstitüsü, Eskişehir.

Yazıcıŏ̆lu, S. (2017). Oyun Temelli Etkinliklerin Ortaokul 6. Sınıf Öğrencilerinin Akademik Başarılarına, Fen Öğrenmeye Yönelik Motivasyonlarına ve Tutumlarına Etkisi: Işık ve Ses Ünitesi Örneği (Yayımlanmamış Yüksek Lisans Tezi). Giresun Üniversitesi Fen Bilimleri Enstitüsü, Giresun

Yıldırım, B. (2015). Eğitsel Oyun ve Dönüt-Düzeltmenin Öğrenme Düzeyi ve Kalıcllğa Etkisi. (Yayımlanmamış Yüksek Lisans Tezi). Necmettin Erbakan Üniversitesi Eğitim Bilimleri Enstitüsü, Konya.

Yüksel, H. (2019). Türkçe Dersinde Kullanılan Eğitsel Dijital Oyunların Ders Başarısı ve Motivasyona Etkisi (Yayımlanmamış Yüksek Lisans Tezi). Zonguldak Bülent Ecevit Üniversitesi Sosyal Bilimler Enstitüsü, Zonguldak. 
Zin, N. A. M., Yue, W. S. \& Jaafar, A. (2009). Digital Game-Based Learning (DGBL) Model and Development Methodology for Teaching History. WSEAS Transactions on Computers, 8(2), 322-333. 